\title{
Akut Miyeloid Lösemide Akirin2 Geninin Iffadesi
}

\author{
Tülin Özkan ${ }^{1}$, Buket Altınok², Aynur Karadağ ${ }^{1}$, Arzu Zeynep Karabay ${ }^{3}$, Yalda Hekmatshoar ${ }^{1}$, \\ Nilgün Sayınalp ${ }^{4}$, Asuman Sunguroğlu ${ }^{1}$ \\ ${ }^{I}$ Ankara Üniversitesi Tıp Fakültesi Tıbbi Biyoloji Anabilim Dall, Ankara, Türkiye \\ ${ }^{2}$ Ankara Üniversitesi Săglık Hizmetleri Meslek Yüksekokulu, Ankara, Türkiye \\ ${ }^{3}$ Ankara Üniversitesi Eczacllık Fakültesi, Biyokimya Anabilim Dall, Ankara, Türkiye \\ ${ }^{4}$ Hacettepe Üniversitesi İç Hastalıkları Anabilim Dalı Hematoloji Bilim Dalı, Ankara, Türkiye \\ E-mail: tlnozkan@yahoo.com
}

\begin{abstract}
Özet
Akut miyeloid lösemi (AML), farklı genetik anomaliler gösteren bir grup klonal hematopoetik kök hücre bozukluğudur. Lösemik kök hücrelerin kendini yenileme ve farklılaşmaları arasındaki hassas dengeyi, çeşitli genler ve bu genlerin düzenlediği sinyal yolakları kontrol etmektedir. Wnt/ $\beta$-katenin sinyal yolağı, $\beta$-kateninin regülasyonu aracılı̆̆ıla hematopoetik kök hücrelerin kendilerini yenilemelerini kontrol etmektedir. Akirin2 proteini ise, immünite, $\mathrm{NF \kappa B}$ ve Wnt/ $\beta$-katenin sinyal yolaklarında çok önemli rolleri olduğu düşünülen yüksek derecede korunmuşluk gösteren bir proteindir. $\mathrm{Bu}$ çalışmada $\beta$-katenin gen ekspresyonu yüksek olan AML hastalarının CD34+ hematopoetik kök hücrelerinde Akirin2 geninin ifadesi araştırılmıştır. Sonuç olarak Akirin2 gen ifadesinin AML hastalarının CD34+ hematopoetik kök hücrelerinde sağlıklı bireylere göre anlamlı derecede artmış olduğu tespit edilmiş ve Akirin2 geninin AML patogenezinde önemli rollerinin olabileceğine dair ilk veriler elde edilmiştir.
\end{abstract}

Anahtar Kelimeler: AML, Akirin2, $\beta$-katenin

\begin{abstract}
Acute myeloid leukemia is a type of clonal hematopoietic stem cell disorder displaying different genetic abnormalities. The critical balance between the self-renewal and differentiation of leukemia stem cells are regulated by various genes and signaling pathways that are regulated by these genes. Wnt/ $\beta$-catenin signaling pathway controls the self-renewal of hematopoietic stem cells by the regulation of $\beta$-catenin. Akirin-2 is an evolutionarily conserved nuclear protein which is thought to play important roles in immunity, NFאB and $\mathrm{Wnt} / \beta$-catenin signaling pathways. In this study, expression of Akirin-2 gene was investigated in the CD34+ hematopoietic stem cells of patients with high $\beta$-catenin gene expression. Our results showed that the expression level of Akirin-2 gene was significantly higher in $\mathrm{CD} 34+$ hematopoietic stem cells of patients compared to healthy subjects and Akirin-2 gene could have an important role in AML pathogenesis.
\end{abstract}

Key Words: AML, Akirin2, $\beta$-catenin 


\section{Giriş}

Karsinogenez, çok faktörlü ve çok basamaklı bir olgudur. Karsinogeneze yol açtıkları belirlenen protoonkogenler ve tümör baskılayıcı genlerdeki mutasyonlar, gen amplifikasyonları ve delesyonları ve füzyon proteinleri ile sonuçlanan translokasyonlar, kanser genomu üzerine yapılan çalışmalar sayesinde tanımlanmaya devam etmektedir (Holliday vd 2006). Birden fazla gendeki mutasyonlar nedeniyle oluştuğu bilinen bu nedenle genetik bir hastalık olan kanserin yaklaşı \%85-90'1 sporadik olarak ortaya çıarken, \%10-15'lik bir kısmı kalıtımsal karakterdedir.

Her yıl teşhis edilen kanser vakalarının yaklaşık \%7'sini hematolojik malignansiler oluşturmaktadır. Bu malignansiler arasında yer alan akut miyeloid lösemi (AML), erişkinlerde görülen en yaygın lösemidir. AML, erken hematopoetik kök hücrelerde bir dizi genetik değişiklik sonucunda normal hematopoetik büyüme ve farklılaşmanın bozulması sonucunda, kemik iliği ve periferik kanda çok sayıda anormal olgunlaşmamış miyeloid hücrenin (miyeloblast) birikimi ile karakterize olan bir hastalıktır (Stone vd 2004). 2010 yılında AML teşhisi koyulan 12330 yeni vaka olduğu ve AML' ye bağl1 8950 ölüm gerçekleştiği belirlenmiştir (Jemal vd 2010). Löseminin, normal hematopoetik kök hücrelerden farklı olarak, anormal ve zayıf olarak düzenleme gösteren bir organogenez sürecine uğrayan birkaç lösemik kök hücre tarafından başlatıldığ 1 ortaya konulmaktadır (Passegue vd 2003). Bu bağlamda, löseminin tedavisine yönelik yaklaşımların geliştirilebilmesi için öncelikle, olgunlaşmamış kan hücre tiplerinden olgunlaşmış ve özelleşmiş kan hücrelerinin oluşumu olarak tanımlanan hematopoezis sürecinin iyi anlaşılması gerekmektedir. Bu süreçte özellikle lösemik kök hücre oluşumuna yol açan sinyal yolaklarının aydınlatılarak, bu hücre popülasyonunun kaderinin yönlendirilmesi önem kazanmaktadır.

Lösemik kök hücrelerin kendini yenileme ve farklılaşmaları arasındaki hassas dengeyi, çeşitli genler ve bu genlerin düzenlediği sinyal yolakları kontrol etmektedir. Wnt/ $\beta$-katenin, NFkB, Notch, Hh (Hedgehog), TGF- $\beta$ (transforming growth factor- $\beta$ ), PTEN (Phosphatase and tensin homolog deleted on chromosome ten) ve Bmi bu dengeden sorumlu başlıca sinyal yolaklarıdır ve anormal aktivasyonları lösemi gelişimiyle ilişkilendirilmektedir (Woodward vd 2005).

$\mathrm{Bu}$ sinyal yolakları arasında yer alan Wnt/ $\beta$-katenin sinyal yolağı, embriyonik gelişimde ve erişkinlerde organ ve dokuların devamlılığın sağlanmasında önemli rol oynamaktadır (Wodarz vd 1998). Geçtiğimiz 20 yıl boyunca yapılan pek çok çalışma, Wnt kanonikal sinyal yolağının, çeşitli kanserlerin de aralarında bulunduğu geniş bir hastalık grubunun patogenezinde görev yaptığını ortaya koymuştur. Son zamanlardaki çalışmalar Wnt yolağının aynı zamanda, $\beta$-kateninin regülasyonu aracılı̆̆ıyla hematopoetik kök hücrelerin kendilerini yenilemelerini de kontrol ettiğini göstermektedir (Reya vd 2003, Murdoch vd 2003). AML, normal erken hematopoetik hücrelere benzeyen farklılaşmamış öncü hücre kümelerinin varlığı ile karakterize olmasından dolayı bu hastalığın lösemiyogenezinde Wnt/ $\beta$-katenin sinyal yolağı kritik bir rol oynamaktadır.

Wnt/ $\beta$-katenin sinyal mekanizması incelendiğinde, istirahat halindeki normal hücrede, Wnt aktivasyonu yokluğunda, $\beta$-kateninin hücre membranında yerleşik olduğu ve hücre yüzeyinde Ekaderin ve $\alpha$-katenin ile kompleks oluşturarak hücre iskeleti ile bağlantı yaptığı, (Perez-Moreno vd 2003) Wnt sinyal aktivasyonunun ardından $\beta$-kateninin çekirdeğe taşındığı ve bir transkripsiyon faktörü gibi çekirdekte TCF/LEF (T Cell Factor/Lenfosit enhancer binding factor)'e bağlanarak çok sayıda genin transkripsiyonunu aktive ettiği belirlenmiş̧tir (Ilyas vd 2005).

$\mathrm{Bu}$ çalışmada Wnt/ $\beta$-katenin sinyal yolağında önemli rol aldığ 1 bilinen Akirin2 geninin, AML patogenezindeki ifade düzeyi araştııılmıştır. Bu amaçla çalışmamızda AML hastalarının ve sağlıklı bireylerin CD34+ hematopoetik kök hücreleri izole edilmiş ve bu hücrelerde Akirin2 geninin ifade düzeyleri araştırılmıştır.

\section{Çalışma Grubunun Oluşturulması}

Bu çalışma Ankara Üniversitesi Tıp Fakültesi Tıbbi Biyoloji Ana Bilim Dalı Laboratuvar'ında gerçekleştirilmiştir. Hacettepe Üniversitesi Hematoloji Bilim Dallından AML tanısı almış, 4 hasta ve 
daha önceden her hangi bir malign hastalık tanısı almamış 2 sağlıklı bireyin kemik iliği (K.İ)/kan örnekleri dahil edilmiştir.

RNA'ları çalışılacak bireylerin çalışmaya dahil edilmelerine dair izin kağıtları kendilerinden ve/veya yakınlarından alınmıştır. (Hacettepe Ü. Tıp Fak. Etik kurul tarafından 26.02.2009 tarih ve TBK 09/9-47 karar nolu etik kurul ile onaylanmıştır.)

\section{CD34 $^{+}$Hematopoetik Kök Hücre İzolasyonu}

İlk olarak hasta ve sağlıklı bireylerden alınan örneklerden (kemik iliği/kan) CD34+ hematopoetik kök hücre izolasyonu yapılmıştır. CD34+ hücrelerin eldesi için EasySep CD34+ izolasyon kitinin (Stem cell, Kanada) protokolü izlenmiştir.

\section{RNA Ekstraksiyonu}

Hasta ve sağlıklı bireylerden alınan örneklerden CD34+ hücre izolasyonu yapıldıktan sonra tüm örneklerden Trizol (Invitrogen, ABD) ile RNA izolasyonu yapılmıştır. Elde edilen RNA'ların konsantrasyonu ve saflığ1 spektrofotometrik yöntemle belirlenmiş ve daha sonra \%1'lik Agaroz Jel'de yürütülerek RNA bütünlüğü görüntülenmiştir.

\section{Kantitatif Eş Zamanlı Polimeraz Zincir Reaksiyonu (Quantitative Real Time PCR)}

$\mathrm{Bu}$ çalışmada qRT-PCR yöntemi kullanılarak Akirin2 geni ifadesi kantitatif olarak analiz edilmiştir. İlk olarak CD34+ hematopoetik kök hücrelerden izole edilen RNA örneklerinden $500 \mathrm{ng}$ kullanılarak "Transcriptor High Fidelity c-DNA synthesis kit" (Roche, Almanya) ile c-DNA sentezlenmiştir.

qRT-PCR uygulamalarında kullanılacak olan Akirin2 ve Hprt (hypoxanthine-guanine phosphoribosyltransferase) genlerine özgü primerler (Alpha DNA,USA). "Perl Primer" programı kullanılarak tasarlanmıştır.

Akirin 5'F: ACGAGTTTCCAACAGACAG

Akirin 5'R: TTCACAGATCATCCCAACC

Hprt: 5'F: TGACACTGGCAAAACAATGCA

Hprt: 5'R: GGTCCTTTTCACCAGCAAGCT

"SYBR Green" (Roche, Almanya) floresans boyası kullanılarak $95^{\circ} \mathrm{C}$ 'de 10 dakika, $95^{\circ} \mathrm{C}$ 'de 30 saniye, $60^{\circ} \mathrm{C}^{\prime}$ de 30 saniye, $72^{\circ} \mathrm{C}$ 'de 30 saniye olacak şekilde kantitasyon (qRT-PCR) yapılmıştır.

\section{İstatistiksel Analiz}

Eş zamanlı PCR sonuçları one sample $t$ test'e göre analizlenmiştir. $\mathrm{p} \leq 0.05$ olanlar istatistiksel olarak anlamlı kabul edilmiştir.

\section{Sonuçlar}

Hasta ve sağlıklı bireylerden alınan örneklerden CD34+ hematopoetik kök hücre izolasyonu EasySep CD34+ izolasyon kitinin (Stem cell, Kanada) protokolüne göre yapılmıştır (Şekil 1).

İzole edilen hücrelerden RNA izolasyonu gerçekleştirilmiş (Şekil 2) ve 500ng'dan cDNA sentezi yapılmıştır. Daha sonra qRT-PCR yapılarak hastaların CD34+ hücrelerindeki Akirin2 geni ifadesi sağlıklı bireylerin CD34+ hücrelerindeki Akirin2 geni ifadesine göre kıyaslanmıştır.

Yapılan analizler sonucunda çalış1lan tüm örneklerde Akirin2 geni ifadesi istatistiksel olarak anlamlı derecede yüksek bulunmuştur. Hastalardaki akirin2 geni ifadesindeki kat artışı sırasıyla 2.2, 6.3, 3.2 ve 2.4 kat olarak tespit edilmiştir (Şekil 3). 


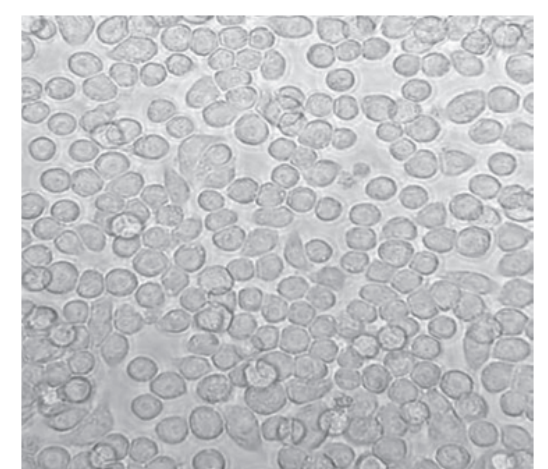

Şekil 1. İzole edilen CD34+ hücrelerin mikroskobik görüntüleri (10X 40 büyütme)

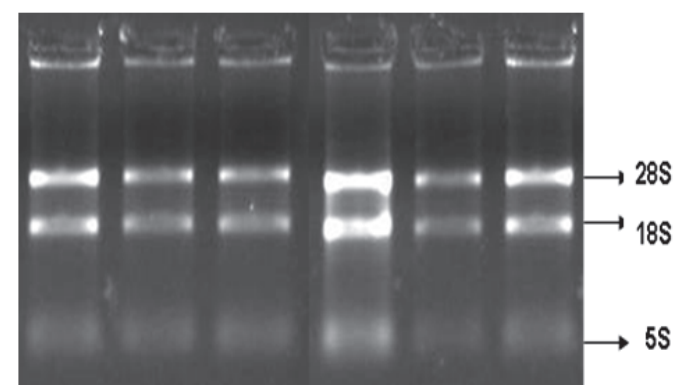

Şekil 2. CD34+ Hücrelerden izole edilen RNA'ların \%1'lik Agaroz Jel görüntüsü

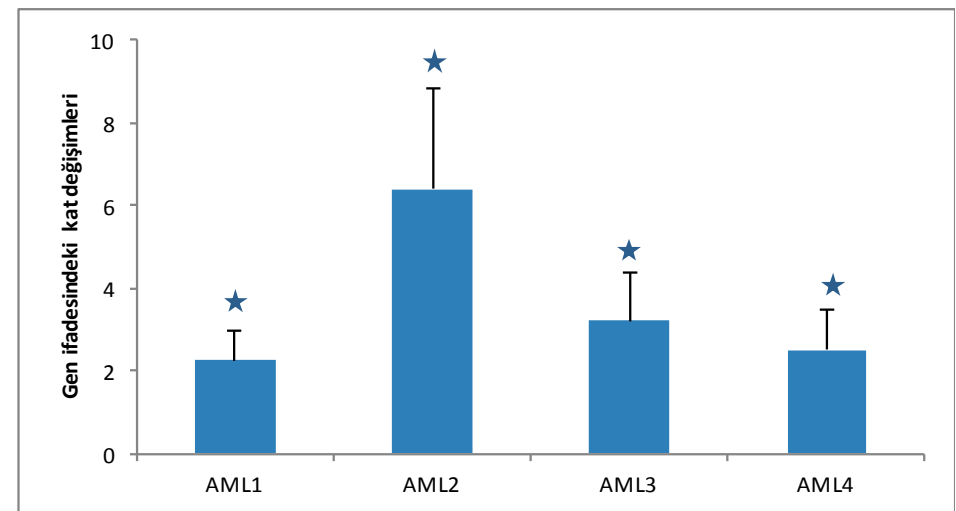

Şekil 3. Akirin2 geni ifadesi sonuçları. AML hastalarının CD34+ hücrelerindeki Akirin2 geni ifadesinin sağllklı bireylerdeki CD34+ hücrelerindeki Akirin2 geni ifadesine oranı. $\star_{p \leq 0.05}$

\section{Tartışma}

NFkB ve Wnt//-katenin sinyal yolaklarının bir çok kanserde çok önemli rollerinin olduğu bilinmektedir ve bu yüzden bu yolaklar kanserin tedavisinde sıklıkla hedeflenmektedirler. Akirin2, immünite, $\mathrm{NF \kappa B}$ ve Wnt/ $\beta$-katenin sinyal yolaklarında çok önemli rolleri olduğu düşünülen yüksek derecede korunmuşluk gösteren bir proteindir (Beutler vd 2008, Goto vd 2008). Ancak bu zamana kadar Akirin2'nin kanserdeki rolü tam olarak açıklanamamıştır.İmmün yanıt yolaklarında görev aldığı

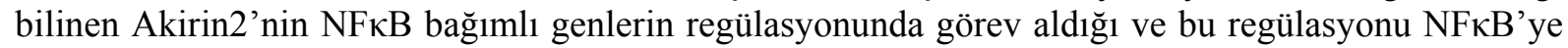
tanımlanmayan bir protein aracılığıyla bağlanarak yaptığı düşünülmektedir. Akirin2 genetik olarak Wnt sinyal yolağıyla etkileşmektedir ve bu interaksiyonun $\beta$-katenin ile doğrudan bir etkileşimle ya da adaptör proteinler aracılığılla gerçekleştiği önerilmektedir (Beutler vd 2008). Bunun yanı sıra Wnt/ß- 
katenin yolağının löseminin ilerlemesi ve ilaç direnciyle de yakından ilişkili olduğu bilinmektedir (Scheller vd 2013). Bu çalışmada daha önceden $\beta$-katenin geni ifadesi yüksek bulunan hastalarda Akirin2 geninin de ifadesi araştırılmış ve AML hastalığının patogenezindeki rolüne dair ön bulgular elde edilmiştir. Akirin2 gen ekspresyonunun AML hastalarının CD34+ hematopoetik kök hücrelerinde sağlıklı CD34+ hematopoetik kök hücrelerine göre anlamlı derecede arttığı saptanmıştır. Bu bulgular Akirin2'nin AML patogenezinde önemli rolü olabileceğine dair ilk bulgulardır. Akirin2 geninin AML'deki rolünün daha iyi anlaşılması için daha ileri çalışmaların yapılması gereklidir.

\section{Kaynaklar}

Beutler B, Moresco EM. 2008. Akirins versus infection. Nat Immunol, 9:7-9.

Goto A, Matsushita K, Gesellchen V, El Chamy L, Kuttenkeuler D, Takeuchi O, Hoffman JA, Akira S, Boutros M, Reichhart JM. 2008. Akirins are highly conserved nuclear proteins required for NF-kappaB-dependent gene expression in drosophila and mice. Nat Immunol, 9: 97-104.

Holliday, R. 2006. Epigenetics: a historical overview.Epigenetics, 1: 76-80.

Ilyas, M. 2005. Wnt signalling and the mechanistic basis of tumour development. J Pathol, 205: (2):130-144.

Jemal, A., Siegel, R., Xu, J., Ward, E. 2010. Cancer statistics. CA Cancer J Clin, 2010;60:277-300.

Murdoch, B., Chadwick, K., Martin, M, et al. 2003. Wnt-5A augments repopulating capacity and primitive hematopoietic development of human blood stem cells in vivo. Proc Natl Acad Sci USA, 100:3422-3427.

Passegué, E., Jamieson, CH., Ailles, LE., Weissman, IL. 2003. Normal and leukemic hematopoiesis: are leukemias a stem cell disorder or a reacquisition of stem cell characteristics? Proc Natl Acad Sci U S A. 30;100 Suppl, 1:11842-9.

Perez-Moreno, M., Jamora, C., Fuchs, E. 2003. Sticky business: orchestrating cellular signals at adherens junctions. Cell, 112, 535-548.

Reya, T., Duncan , AW., Ailles, L., Domen, J., Scherer, DC., Willert, K., Hintz, L., Nusse, R., Weissman, IL. 2003. A role for Wnt signalling in self-renewal of haematopoietic stem cells. Nature, 423:409-414.

Scheller M, Schonheit J, Zimmermenn K, Leser U, Rosenbauer F, Leutz A. 2013. Cross talk between Wnt/Bcatenin and Irf8 in leukemia progression and drug resistance. The Journal of Experimental Medicine, 210: 2239-2256.

Stone, R.M., O'donnell, M.R., Sekeres, M.A. Acute Myeloid Leukemia. 2004. Hematology Am Soc Hematol Educ Program. 98-117.

Tan, X. 2008. Beta-catenin deletion in hepatoblasts disrupts hepatic morphogenesis and survival during mouse development. Hepatology, 47:1667-1679.

Wodarz, A., Nusse, R. 1998. Mechanisms of Wnt signaling in development. Annu Rev Cell Dev Biol, 14:59-88.

Woodward, W.A., Chen, M.S., Behbod, F., Rosen, J.M. On mammary stem cells. 2005. J Cell Sci, 118 (Pt 16):3585-94. 